\title{
Perinatal mortality, growth and survival to weaning in offspring of rats reared on diets moderately deficient in protein
}

\author{
By M. R. TURNER* \\ Human Nutrition Research Unit, Medical Research Council of Great Britain, \\ and Department of Physiology and Biochemistry, University of Southampton
}

$$
\text { (Received } 28 \text { fune } 1972-\text { Accepted } 7 \mathfrak{F u l y} \text { 1972) }
$$

I. The reproductive performance of rats reared from weaning on a moderately proteindeficient (LP) diet containing $80 \mathrm{~g}$ casein $/ \mathrm{kg}$, or on a control diet (HP) containing $250 \mathrm{~g}$ casein $/ \mathrm{kg}$ has been studied. Although the rate of growth was reduced in LP animals, these rats eventually achieved the same adult weight and appearance as the controls.

2. Weight gajn during the first 2 weeks of gestation was similar in the two dietary groups, but during the 3 rd week $H P$ rats gained twice as much weight as the LP animals.

3. Viable litters were produced by $78 \%$ of the HP rats mated but by only $33 \%$ of LP rats. Most of the offspring which died did so during or soon after birth; so the perinatal mortality for the offspring of LP rats was $73 \%$ compared with only $26 \%$ for control rats. After the first few days of life, the chance of survival of HP and LP offspring was similar.

4. At birth the mean body-weight of the offspring was $5.4 \mathrm{~g}$ for HP offspring and $4.7 \mathrm{~g}$ for LP offspring. However, the mean body-weight at birth of viable offspring was similar whether they were from HP or LP rats (HP $5.6 \mathrm{~g}$; LP $5 \cdot 3 \mathrm{~g}$ ). At weaning, HP offspring weighed $3 \mathrm{I} \cdot 2 \mathrm{~g}$ and LP offspring only $13.3 \mathrm{~g}$.

5. When the HP diet was given to LP rats at parturition, the viable offspring achieved a weaning weight of $31^{\prime} 5 \mathrm{~g}$, but there was no decrease in the perinatal mortality.

Severe food restriction results in infertility in women (Antanov, 1947; Smith, 1947) and poor reproductive performance in the rat, even when food intake is restricted only during reproduction (Nelson \& Evans, 1953; Chow \& Lee, r 964). A severe restriction of dietary protein usually results in a reduction in energy intake as well, which in itself would impair reproductive performance. Certainly a diet containing $20 \mathrm{~g}$ casein $/ \mathrm{kg}$ is inadequate for the maintenance of pregnancy in the rat whether due to a lack of protein, energy, or both (Aschkenasy-Lelu \& Aschkenasy, I957). On the other hand, a less severe restriction in dietary protein imposed only during gestation may have little effect on the weight and size of the litter at term, as has been shown with a roo $g$ casein/ $\mathrm{kg}$ diet (Naismith, 1966 ) or at birth when a $70 \mathrm{~g}$ wheat-protein $/ \mathrm{kg}$ diet was offered (Venkatachalam \& Ramanathan, I964). These observations support the idea that the foetus can obtain the nutrients it needs at the expense of the maternal tissues (Hammond, 1944). Except in instances of severe dietary inadequacy this may well be true during gestation, but is apparently less so during the lactation period when the nutrient demands on the mother are particularly high. Thus in Venkatachalam \& Ramanathan's (I964) experiments, although the $70 \mathrm{~g}$ wheat-protein $/ \mathrm{kg}$ diet supported pregnancy, there was a slower postnatal growth and a higher death rate in the offspring of the protein-deficient mothers.

* Present address: Department of Physiology and Biochemistry, The University, Southampton $\mathrm{SO}_{9}{ }_{5} \mathrm{NH}$. 
When rats are reared from weaning on protein-deficient diets, reproductive performance may also be impaired, as judged by the number and weight of offspring brought to weaning (Goettsch, 1949; Stewart \& Sheppard, 1971; Widdowson \& Cowen, 1972). It is not clear, however, to what extent the smaller number of offspring reaching weaning is a consequence of inadequate lactation by the mother and to what extent earlier events may be responsible. The work reported here attempts to clarify this point.

\section{EXPERIMENTAI}

Female rats, bred at Mill Hill from a Hooded Lister stock, were housed at $22 \cdot 5 \pm 2^{\circ}$ in wire-mesh cages. Humidity was maintained by flooding the floor twice daily. In addition to normal daylight, artificial light was supplied for $\mathrm{I} 2 \mathrm{~h} / \mathrm{d}$.

Table I. Composition of control $(H P)$ and moderately protein-deficient

$$
(L P) \text { diets }
$$

\begin{tabular}{|c|c|c|}
\hline \multirow[b]{2}{*}{ Dried, milled constituent } & \multicolumn{2}{|c|}{ Amount in diet $(\mathrm{g} / \mathrm{kg})$} \\
\hline & HP & LP \\
\hline Casein (Casumen) & 250 & 80 \\
\hline Carbohydrate* & 350 & 520 \\
\hline Cellulose (Solka Floct) & 100 & 100 \\
\hline Sucrose & 150 & 150 \\
\hline Arachis oil & 100 & 100 \\
\hline Salt mixture (Jones \& Foster, 1942) & 40 & 40 \\
\hline Vitamin mixture & IO & Io \\
\hline NDp : E (NDpCal \%) & 0.1 I $5($ I I 5$)$ & $0.051(5.1)$ \\
\hline
\end{tabular}

NDp: E, ratio of energy supplied by utilizable protein to total metabolizable energy.

Fat-soluble vitamins were supplied orally as o. I ml/rat per week of a solution in arachis oil of: retinol $0.6 \mathrm{mg} / \mathrm{l}$, ergocalciferol $7.5 \mu \mathrm{g} / \mathrm{ml}$, $\alpha$-tocopherol acetate $5 \mathrm{mg} / \mathrm{ml}$, menaphthone $3.32 \mathrm{mg} / \mathrm{ml}$.

* Supplied as sucrose or as maize starch.

† Johnson, Jörgensen \& Wettre Ltd, London EC4.

$\ddagger$ Composition (mg/kg): biotin 3.9 , cobalamin $0 \cdot r$, folic acid 39 , inositol 3900 , nicotinic acid 975 , calcium pantothenate 1160 , pyridoxine hydrochloride 39 , riboflavin 193 , thiamin hydrochloride 58 , choline hydrochloride I $1000, p$-aminobenzoic acid I I 000 , maize starch to I $\mathrm{kg}$.

Expt 1. Rats were weaned at $23 \mathrm{~d}$ of age at $35 \pm 5 \mathrm{~g}$ body-weight and allocated at random to an $80 \mathrm{~g}$ casein $/ \mathrm{kg}$ diet (LP) or a $25^{\circ} \mathrm{g}$ casein $/ \mathrm{kg}$ diet (HP) offered ad lib.: the composition of the diets is shown in Table $I$. They were weighed regularly and their food intake was measured from time to time during growth, and throughout pregnancy and lactation.

As they approached $150 \mathrm{~g}$ in body-weight, which occurred at about 4 months of age in HP rats and 6 months of age in LP rats, they were separated into individual cages and males were introduced. The presence of a mating plug was regarded as evidence of a successful mating. During gestation, food intake and body-weight were measured over each weekly period. On the 2ist day of gestation, wood-wool was introduced as a nesting material; a litter was looked for each morning and afternoon. Gestation in both dietary groups was of $22-23 \mathrm{~d}$ duration. The mother and litter were weighed $24 \mathrm{~h}$ after the litter was first observed and subsequently on days $4,7,14$ and 21 post partum. The cumulative results reported are from first pregnancies only and were obtained 


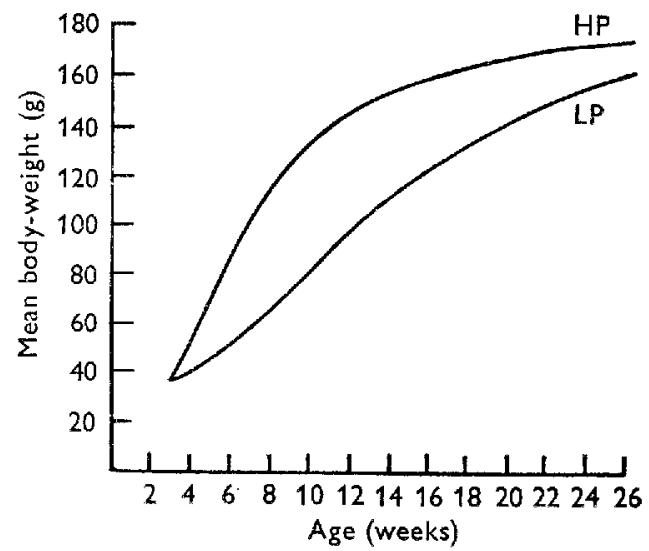

Fig. I. Mean body-weight gain with increasing age in rats weaned on to a control diet (HP) containing $250 \mathrm{~g}$ casein/kg or a moderately protein-deficient diet (LP) containing $80 \mathrm{~g}$ casein $/ \mathrm{kg}$.

Table 2. Mean body-weight and food intake of growing rats receiving a control $(H P)$ or a moderately protein-deficient diet $(L P)$

\begin{tabular}{|c|c|c|c|c|c|c|}
\hline \multirow[b]{3}{*}{$\begin{array}{c}\text { Age } \\
\text { (weeks) }\end{array}$} & \multicolumn{3}{|c|}{$\mathrm{HP}$} & \multicolumn{3}{|c|}{ LP } \\
\hline & \multirow[b]{2}{*}{$\begin{array}{c}\text { Body-wt } \\
(\mathrm{g})\end{array}$} & \multicolumn{2}{|c|}{ Food intake } & \multirow[b]{2}{*}{$\begin{array}{c}\text { Body-wt } \\
(\mathrm{g})\end{array}$} & \multicolumn{2}{|c|}{ Food intake } \\
\hline & & $\begin{array}{c}\text { Wt } \\
(\mathrm{g} / \text { rat per } \mathrm{d})\end{array}$ & $\begin{array}{c}\text { Energy } \\
\left(\mathrm{J} / \mathrm{kg}^{0 \cdot 73} \text { per } \mathrm{d}\right)\end{array}$ & & $\begin{array}{c}\text { Wt } \\
(\mathrm{g} / \text { rat per } \mathrm{d})\end{array}$ & $\begin{array}{c}\text { Energy } \\
\left(\mathrm{J} / \mathrm{kg}^{0.73} \text { per d }\right)\end{array}$ \\
\hline 4 & 59 & $7 \cdot 6$ & I $10_{5}$ & 42 & $5 \cdot 6$ & Iog6 \\
\hline 9 & 137 & $9 \cdot 8$ & 778 & 66 & $7 \cdot 2$ & 962 \\
\hline 10 & 157 & 10.5 & 766 & - & - & - \\
\hline 12 & - & - & - & 95 & $9 \cdot 2$ & 929 \\
\hline 16 & 178 & $11 \cdot 3$ & 753 & $\begin{array}{l}113 \\
113\end{array}$ & $9 \cdot 3$ & 854 \\
\hline 26 & - & - & - & 160 & $11 \cdot 8$ & 845 \\
\hline
\end{tabular}

from a total of sixty animals in five different batches during a 3 -year period. Results from second and subsequent pregnancies will be reported elsewhere.

Expt 2. In a parallel experiment, rats were killed on the 2ist day of gestation and the number and weight of the foetuses were noted. The mammary tissue from the posterior six glands was excised and weighed; the anterior six glands were set aside for histological and chemical analysis. Additional results from these experiments are reported elsewhere (Turner, 1972).

Expt 3. A further group of twelve rats was fed on the LP diet during growth and pregnancy. From parturition onwards the HP diet was offered; the performance of the mothers and litters was observed until the litters were weaned at $2 \mathrm{I} \mathrm{d}$ of age.

\section{RESULTS}

Weight gain and food intake of non-pregnant rats

Although the rate of body-weight gain was reduced in LP rats, their weight eventually caught up with that of the control animals (Fig. I). As adults, LP were indistinguishable from HP rats in size, appearance, vigour and apparent health. 
Table 3. Mean values with their standard errors $(g)$ for body-zeight and mean values $(g)$ for weight gain during pregnancy and lactation of rats giving birth to viable or non-viable litters and reared from weaning on a control diet $(H P)$ or a moderately protein-deficient diet $(L P)$, or reared on the LP diet and given the HP diet at parturition

(Nos. of animals shown in parentheses)

Period

On day of pregnancy:

Gain in days:

$$
\begin{array}{r}
I-I 4 \\
I 4-2 I \\
I-2 I
\end{array}
$$

On day of lactation:

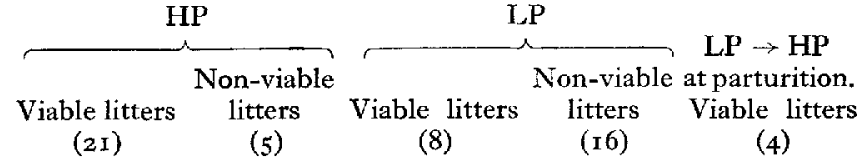

(5)

$$
\begin{aligned}
& 160 \pm 4 \cdot 9 \\
& 174 \pm 5 \cdot 6 \\
& 191 \pm 6 \cdot 8 \\
& 223 \pm 9 \cdot 9
\end{aligned}
$$

31
32
63

I $7 \pm \pm 6.5$
I $62 \pm 7 \cdot 6$
г $54 \pm 6 \cdot 9$
I $35 \pm 4 \cdot 7$
I $25 \pm 3.8$

$-46$

$\begin{array}{ll}\text { I } 6 \mathrm{I} \pm 3 \cdot 8 & \text { I } 47 \pm 3 \cdot 4 \\ \text { I } 75 \pm 3.9 & \text { I } 60 \pm 4 \cdot 9 \\ \text { I } 92 \pm 3.9 & \text { I } 77 \pm 4 \cdot 6 \\ \text { II } 8 \pm 4.9 & 203 \pm 5 \cdot 2\end{array}$

3 I

26

57

30

26

56

$\begin{array}{ll}\mathrm{I} 7 \mathrm{r} \pm 4.2 & \text { I } 55 \pm 3.7 \\ & 169 \pm 6.3 \\ & 172 \pm 4 \cdot 2 \\ & 176 \pm 5.1 \\ & 172 \pm 6.4\end{array}$

I7

The food intake of LP animals was less than that of the controls at all ages during the growing phase (Table 2). However, for any body-weight, the food consumption in the two dietary groups was similar. When the values were expressed as $\mathrm{J} / \mathrm{kg}^{0 \cdot 73}$ per $\mathrm{d}$, the LP rats tended to eat more at any given age (Table 2 ). Therefore LP rats can be regarded as protein-deficient, but not energy-deficient. Their rate of growth was limited by their protein intake, but their energy intake was always appropriate for an animal of their particular body-weight. In this respect they differed from animals subjected to energy restriction, or to a protein and energy restriction.

\section{Weight gain and food intake of pregnant rats}

During the first 2 weeks of gestation, there was little difference in weight gain between the two dietary groups (HP, $3^{8} \mathrm{~g} ; \mathrm{LP}, 3^{\mathrm{I}} \mathrm{g}$ ). During the $3^{\mathrm{rd}}$ week, however, the $\mathrm{HP}$ rats gained nearly twice as much weight as their LP counterparts (HP 55 g; LP, $28 \mathrm{~g}$ ) (Table 3). This difference was not related to food intake, which was similar in both groups during gestation (about $3 \mathrm{IO}$ g) but must be regarded as an effect of the lower protein intake of the LP rats (Table 4 ).

\section{Survival of offspring}

Some rats from both dietary groups produced litters no member of which survived to weaning (non-viable litters). Results are presented separately for viable and nonviable litters and for the rats producing them. 
Table 4. Food intake ( $g$ /rat per d) during pregnancy and lactation of rats giving birth to viable litters and reared from weaning on a control diet $(H P)$ or a moderately proteindeficient diet $(L P)$ or reared on the LP diet and given the HP diet at parturition

(Means for thirty HP and thirty LP non-pregnant, twenty-seven HP pregnant, twenty-one HP lactating, twenty-four LP pregnant, eight LP lactating and four LP $\rightarrow$ HP at parturition)

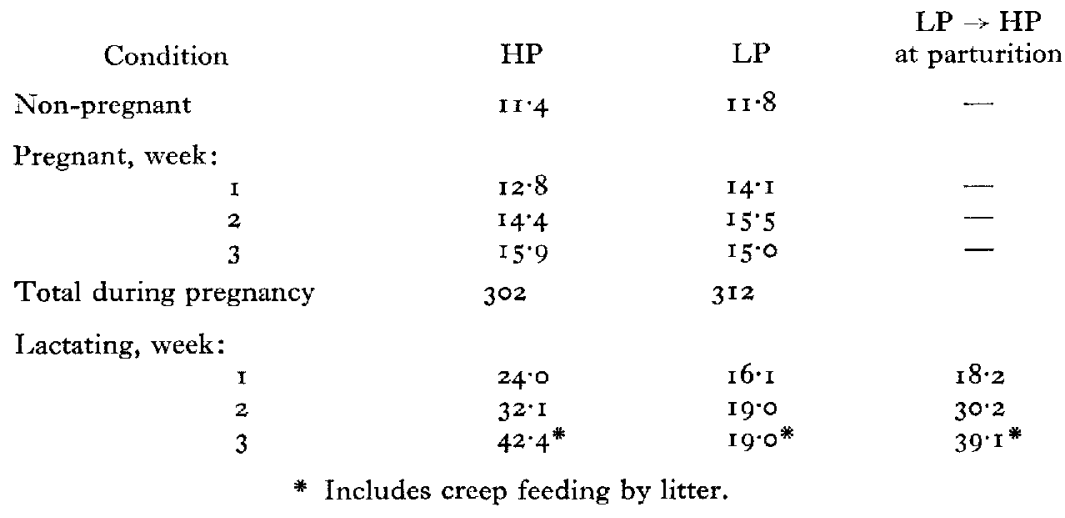

Table 5. Reproductive performance of rats reared from weaning on a control diet $(H P)$ or a moderately protein-deficient diet (LP)

\section{Criterion}

Exposed to males

Mated

Resorbed

Full-term litters not delivered

Foetuses alive at term*

\begin{tabular}{|c|c|}
\hline Litters born & $2 I$ \\
\hline \multicolumn{2}{|l|}{ Offspring alive: } \\
\hline post partum, day I & 225 \\
\hline 4 & 210 \\
\hline 7 & 20 \\
\hline 14 & 204 \\
\hline $2 \mathrm{I}$ & 201 \\
\hline
\end{tabular}

Perinatal mortality (\%):

\section{HP}

30

$$
29
$$

2

0

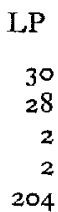

204

Viable litters

8
56
55
54
54
54

8

56

55

54

54

54

LP

28
Non-viable litters

I6

46

$\circ$

o

0

to day

I 6

26

50

* Determined from a parallel series of experiments.

From HP rats, $78 \%$ of the litters were viable, compared with only $33 \%$ from LP animals. Thus the total numbers of offspring weaned from twenty-seven HP and twenty-four LP litters born were $20 \mathrm{I}$ and $5^{\mathrm{I}}$ respectively. Expressed as offspring weaned per rat mated, this represents a reproductive performance of 6.9 for HP rats and $2 \cdot 0$ for LP animals (Table 5 ).

The LP litters were always smaller than those of HP animals, even before parturition. 
Thus on the 2rst day of gestation the HP litters contained a mean of $I$ I $\cdot 3$ foetuses/ litter and the LP animals 8.5 foetuses/litter $(P<0.001)$. After birth there was a similar difference in the size of viable litters (HP Io.6 offspring/litter, LP 7.0 offspring/ litter; $P<0.001$ ), which was maintained to weaning ( $\mathrm{HP} 9.7$ offspring/litter, LP 6.4 offspring/litter; $P<0.001$ ). Therefore, within viable litters there was little difference between dietary groups in postnatal mortality (HP 8.5\% loss, LP 8.6\% loss). The death of LP offspring can also be expressed as the perinatal mortality by comparing the litter size before birth with the number of live offspring after birth. When this comparison was made between the 21 st day of gestation and the $4^{\text {th }}$ day post partum, by which day most of the non-viable offspring were dead, the perinatal mortality in the LP group was very high (HP $26 \%, \mathrm{LP} 73 \%$ ) (Table 5).

\section{Weight of offspring}

The weaning weight of offspring of LP rats was reduced (HP $3 \mathrm{I} \mathrm{g}, \mathrm{LP}$ I3 $\mathrm{g}$; $P<0.001$ ) (Table 6). Thus the total weight of conceptus brought to weaning, as $g$ offspring/rat mated, was about $215 \mathrm{~g}$ for HP rats but only about $27 \mathrm{~g}$ for LP rats. On the Ist day after birth, however, there was no significant difference between the mean weight of viable offspring from HP and LP rats ( $\mathrm{HP} 5 \cdot 6 \mathrm{~g}, \mathrm{LP} 5 \cdot 3 \mathrm{~g}$ ).

\section{Table 6. Mean body-weight of offspring of rats reared from weaning on a control diet $(H P)$ or a moderately protein-deficient diet $(L P)$}

(Mean values with their standard errors for twenty-one viable HP litters, six non-viable HP litters, eight viable LP litters and sixteen non-viable LP litters)

\begin{tabular}{|c|c|c|c|c|}
\hline & \multicolumn{4}{|c|}{ Mean body-weight/pup (g) } \\
\hline & \multicolumn{2}{|c|}{$\mathrm{HP}$} & \multicolumn{2}{|c|}{ LP } \\
\hline Day after birth: & Viable litters & $\begin{array}{l}\text { Non-viable } \\
\text { litters }\end{array}$ & Viable litters & $\begin{array}{c}\text { Non-viable } \\
\text { litters }\end{array}$ \\
\hline I & $5 \cdot 6 \pm 0 \cdot 1$ & $4 \cdot 8 \pm 0.3 \uparrow t$ & $5 \cdot 3 \pm 0 \cdot 2$ & $4 \cdot I \pm 0 \cdot r+t+$ \\
\hline 4 & $8 \cdot 1 \pm 0.2$ & - & $6.4 \pm 0.3 * * *$ & - \\
\hline 7 & $10.9 \pm 0.4$ & - & $7 \cdot 6 \pm 0.3 * * *$ & - \\
\hline 14 & $I 8 \cdot 3 \pm I \cdot 3$ & - & $10.9 \pm 0.2 * *$ & - \\
\hline 21 & $3 I \cdot 2 \pm I \cdot 2$ & - & I $3.3 \pm 0.2 * * *$ & - \\
\hline $\begin{array}{l}\text { Wt of litter weaned/ } \\
\text { rat mated (g) }\end{array}$ & 215 & - & $27 * * *$ & - \\
\hline
\end{tabular}

Statistically significant differences: $* * P<0.01$; *** $P<0.00$ I (HP v. LP); †† $P<0.01$; t+† $P<0.001$ (viable $v$. non-viable).

Note: mean body-weights of all pups alive on day I post partum were: HP, $5.4 \mathrm{~g}$ and LP, $47 \mathrm{~g}$ $(P<0.01)$.

Since more of the LP litters were non-viable and since non-viable offspring from both dietary groups were underweight on the Ist day post partum ( $\mathrm{HP}_{4} \cdot 8 \mathrm{~g}, \mathrm{LP}_{4} \cdot \mathrm{I} \mathrm{g}$ ), the mean birth weight differed between dietary groups when viable and non-viable litters were considered together as a single group (HP $5.4 \mathrm{~g}$, LP $4.7 \mathrm{~g} ; P<0.01$ ). The effect of the LP diet, however, was to increase the number of non-viable litters produced. Viable offspring from both dietary groups were of similar mean body-weight on the ist day post partum and had a similar subsequent rate of survival of offspring to 
Table 7. Mean total weight at term of the posterior six mammary glands of control (HP) and moderately protein-deficient $(L P)$ rats

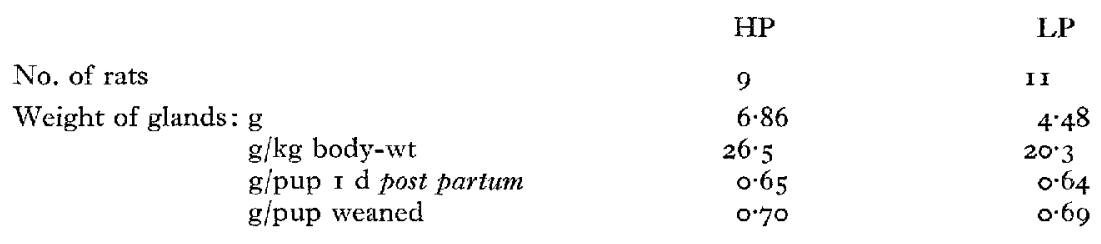

weaning. However, the rate of weight gain to weaning was reduced in LP viable litters (at weaning $\mathrm{HP} 33^{1} \cdot 2 \mathrm{~g}, \mathrm{LP} \mathrm{I}_{3} \cdot 3 \mathrm{~g}$ ).

\section{Lactation}

Although the absolute weight of mammary tissue was reduced in LP rats; so was the litter size even before birth. The weight of mammary tissue per offspring was similar in both dietary groups (Table 7). The histological appearance of mammary tissue from the HP rats was indistinguishable from that of LP rats (B. Christie, personal communication). It would appear, therefore, that the LP rats had an amount of apparently normal mammary tissue similar to that of HP rats when expressed in terms of the litter size at term (HP $0.6 \mathrm{I}, \mathrm{LP} 0.56$ units) on the Ist day post partum (HP 0.65 , LP 0.64 units) or on the 2ist day post partum (HP 0.69 , LP 0.70 units).

The food intake of LP rats during lactation was less than that of the control animals, especially in the 2 nd and 3 rd weeks (Table 4 ). The poor weight gain by LP offspring during lactation suggests that milk production was inadequate in LP rats. Since there was no detectable defect in the mammary tissue, and since the total amount of mammary tissue available per offspring was similar in both dietary groups, it could be that the LP rats were unable to increase their food intake sufficiently to meet the requirement for adequate lactation. This would seem to be confirmed by the fact that the LP mothers of viable litters lost about $27 \%$ of their body-weight during lactation (Table 3 ). When LP rats were given the HP diet from parturition onwards, they did not lose weight during lactation. Their food intake and the weight gain of their offspring were similar to those of HP control animals. However, the number of litters which were non-viable remained unchanged at the level characteristic of LP animals (Table 8).

Table 8. Comparison of the mean body-weight and survival of rats reared from weaning on a control diet $(I P)$ or a moderately protein-deficient diet $(L P)$, or reared on the LP diet and given the HP diet at parturition

\begin{tabular}{|c|c|c|c|}
\hline Criterion & HP & LP & 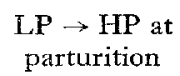 \\
\hline No. of litters born & 27 & 24 & 12 \\
\hline Viable litters $(\%)$ & 78 & 33 & 33 \\
\hline Perinatal mortality $(\%)$ & 26 & 73 & 70 \\
\hline \multicolumn{4}{|l|}{$\begin{array}{l}\text { Mean body-wt of } \\
\text { viable offspring (g): }\end{array}$} \\
\hline day $\mathrm{I}$ & $5 \cdot 6$ & $5 \cdot 3$ & 5.0 \\
\hline day $2 \mathrm{I}$ & $3 I \cdot 3$ & $13 \cdot 3$ & $3 \mathrm{I} \cdot 5$ \\
\hline
\end{tabular}




\section{DISCUSSION}

It is often stated that animals consuming a protein-deficient diet give birth to underweight offspring with a reduced chance of survival (Goettsch, r949; Venkatachalam \& Ramanathan, 1964; Stewart \& Sheppard, 1971; Widdowson \& Cowen, I972). In the experiments described above, it has been shown that both HP and LP rats give birth to some underweight litters with a poor chance of survival and that the effect of the LP diet was to increase the number of underweight non-viable litters produced. The mean body-weight of viable offspring on the ist day post partum and the rate of survival within viable litters were similar in both dietary groups. The rate of weight gain by LP offspring was reduced presumably as a result of a poor milk yield. No defect was seen in the histology of the mammary gland of LP rats and, when the HP diet was given to LP rats at parturition, the food intake of the mother and the weight gain of the offspring were similar to those of HP controls; this suggests that the factor limiting milk production in LP rats was not the mammary gland but the maternal food intake during lactation. Since the food intake by LP and HP rats was similar both before mating and during gestation, the fact that LP rats were unable to increase the intake of the LP diet to meet the nutrient requirement for lactation, but were able to eat larger amounts of the HP diet, raises interesting questions about the mechanism of control of food intake in this situation.

Perinatal mortality was not decreased when the HP diet was given to LP rats at parturition. There was no detectable difference in body-weight or gross body composition between HP and LP foetuses on the 21st day of gestation ('Turner, 1972), but there was a large difference in perinatal mortality in the two dietary groups that was apparent even on the rst day post partum. It is possible to speculate that either there was some undetected defect in the LP foetuses at term or that some aspect of parturition was deranged in LP rats and this resulted in the high perinatal death in the LP group. Since two of the thirty LP rats mated did not give birth to a litter, but were observed to have a fully grown litter in utero in the process of being resorbed $3 \mathrm{~d}$ after the expected day of parturition, one could speculate that prolonged parturition or a failure to initiate labour may have contributed to the high perinatal loss. This needs further investigation.

It has been suggested from experiments in dogs that a mild nutrient deficiency in pregnancy is borne by the mother and a more severe deficiency shared between mother and baby (Platt \& Stewart, 1967, I968). This idea supports the concept of the foetus acting as a parasite, or at least as having a high priority for available nutrients (Hammond, 1944; Naismith, 1969). The results presented here are not at variance with this idea but they do show that a moderate deficiency of dietary protein which is adequate to support slow growth to normal adult size (at which time the HP and LP rats were indistinguishable) was totally inadequate for the production of viable offspring even though there was no lesion detected in the foetuses at term. To what extent comparable long-term variations in the protein content of human diets may affect reproductive ability is difficult to evaluate in precise terms and must at this time remain speculative. 
I am grateful to the late Professor B. S. Platt for the opportunity to undertake these investigations, and to Miss Susan Terry for invaluable support in the later stages of the work.

\section{REFERENCES}

Antanov, A. M. (1947). F. Pediat. 30, 250.

Aschkenasy-Lelu, P. \& Aschkenasy, A. (1957). Archs Sci. physiol. 11, 125.

Chow, B. F. \& Lee, C. J. (1964). F. Nutr. 82, 10.

Goettsch, M. (1949). Archs Biochem. 21, 289.

Hammond, J. (1944). Proc. Nutr. Soc. 2, 8.

Jones, J. H. \& Foster, C. (1942). J. Nutr. 24, 245.

Naismith, D. J. ( I 966). Metabolism r5, 582 .

Naismith, D. J. (1969). Proc. Nutr. Soc. 28, 25.

Nelson, M. M. \& Evans, H. M. (1953). F. Nutr. 51, 7 r.

Platt, B. S. \& Stewart, R. J. C. (1967). Maternal Child Care 3, 539.

Platt, B. S. \& Stewart, R. J. C. (1 968). Devl Med. Child Neurol. ro, 3.

Smith, C. A. (1947). F. Pediat. 30, 229.

Stewart, R. J. C. \& Sheppard, H. G. (I971). Br. J. Nutr. 25, I75.

Turncr, M. R. (1972). Nutr. Rep. int. 5, I.

Venkatachalam, P.S. \& Ramanathan, K. S. (1964). F. Nutr. 84, $3^{8}$.

Widdowson, E. M. \& Cowen, J. (1972). Br. Y. Nutr. 27, 85 . 